\title{
Production of clean synthetic gas from palm shell in a fixed bed gasifier with recycle system of producer gas
}

\author{
Sunu Herwi Pranolo ${ }^{1, *}$, Muhammad Tasmiul Khoir ${ }^{1}$, and Muhammad Fahreza Pradhana ${ }^{1}$ \\ ${ }^{1}$ Sebelas Maret University, Chemical Engineering, Surakarta, Indonesia
}

\begin{abstract}
Tar as side product of biomass gasification could potentially degrade internal combustion engine performance if syngas is used for the fuel. Tar reduction may be achievable with recycling of outlet producer gas back into the gasifier. This research studied the effects of recycle system to tar content in syngas as product of palm shell gasification in a fixed bed gasifier. The effects of recycling system were examined using gasification of palm shell with primary air at $3.30 \mathrm{Nm}^{3} / \mathrm{h}$, mixture of primary air at 1.80 $\mathrm{Nm}^{3} / \mathrm{h}$ and secondary air at $1.50 \mathrm{Nm}^{3} / \mathrm{h}$, and mixture of primary air and recycled gas. Volumetric rate of recycle gas were varied at 0.90 and $1.20 \mathrm{Nm}^{3} / \mathrm{h}$ respectively. Gasification performance evaluation was based on Specific Gasification Rate. Syngas quality was rated with tar content, $\mathrm{CO}, \mathrm{CH}_{4}, \mathrm{H}_{2}, \mathrm{CO}_{2}$, and $\mathrm{N}_{2}$ composition. The highest Specific Gasification Rate of $111.71 \mathrm{~kg} / \mathrm{m}^{2} \mathrm{~h}$ and tar reduction up to $61.95 \%$ were achieved using recycle system at volumetric rate of $0.90 \mathrm{Nm}^{3} / \mathrm{h}$ with temperature of operation is $750^{\circ} \mathrm{C}$. The highest heating value of $6.34 \mathrm{MJ} / \mathrm{Nm}^{3}$ was attained using recycled gas volumetric rate at $1.20 \mathrm{Nm}^{3} / \mathrm{h}$.
\end{abstract}

\section{Introduction}

The declining of fossil fuel availability and unstable price encourage utilization of any renewable energy resources. Biomass as renewable energy plays significant role in this situation. In general, biomass from cultivated plantations or as solid residue of a certain production process would be more technical and economical feasible. Palm oil plantation is an attractive example of this condition. Combination of plantation and production process of crude palm oil provide huge amounts of palm biomass wastes $[1,2]$. It is obvious that the biomass from plantation wastes needs more effort for its utilization as energy source compared with biomass from production process as it needs additional harvesting and transportation.

Currently, both cultivated palm plantation and crude palm oil industry in Indonesia are growing rapidly. The biomass residues of the plantations are mainly oil palm trunks and oil palm fronds. Besides producing the oil, processing fresh fruit bunch (FFB) also generates palm shells, fibers, and empty fruit bunches as solid residues. Those have potential energy when are managed and converted appropriately. Table 1 shows potential energy generated in a typical palm oil milling [1-3]. In palm oil millings, mesocarp fibers (MF) and palm shells (PS) are the significant energy sources for generating process steam and electricity. These are energy sources of interest to power stations rather than the others which are possible generate $120 \mathrm{kWh} /$ ton of FFB. Processing one ton of FFB needs about 0.73 ton of steam, and 20-25 $\mathrm{kWh}$ of electricity. As the availability, relatively high energy content, ease of handling and transportation, the palm shells become a profitable commodity.

Table 1. Potential energy generated in a typical palm oil milling.

\begin{tabular}{|c|c|c|}
\hline Type of biomass & $\begin{array}{c}\text { Potential } \\
\text { availability } \\
\text { (kg/kg FFB) }\end{array}$ & $\begin{array}{c}\text { Potential energy } \\
\text { generated } \\
\text { (MJ/kg) }\end{array}$ \\
\hline Mesocarp fibers & 0.220 & 17.6 \\
\hline Palm shell & 0.055 & 18.5 \\
\hline Empty fruit bunch & 0.135 & 17.9 \\
\hline $\begin{array}{c}\text { Palm oil mill } \\
\text { effluent (POME) }\end{array}$ & 0.670 & 18.9 \\
\hline
\end{tabular}

In this country, palm plantations were cultivated since more than 25 years ago and improved continuously. According to the report of Directorate General of Estate Crops, the area of palm plantations in Indonesia was about $11,260,277$ ha and the palm productivity was 2.76 ton/ha in the year of 2015. Palm dominates plantation areas in Sumatera Island and Kalimantan Island. It is also found in Sulawesi Island and Papua Island in a smaller area. Association of Indonesian Palm Shell Entrepreneurs (APCASI) reported that Indonesia exported 9.2 million tons of palm shell to Japan in 2017.

Utilization of biomass from palm oil milling shows the high potential of C-reduction. The sum of Creduction was found 1.2 times greater than that of $\mathrm{C}$ emission [2]. This figure can be increased up to 5.5, if all biomass by-products are used as fuel to generate

\footnotetext{
* Corresponding author: $\underline{\text { sunu pranolo@staff.uns.ac.id }}$
} 
electricity only. It is also common to express biomass as

carbon-neutral energy resources.

Table 2. Chemical and calorific value analysis of some Indonesian biomasses.

\begin{tabular}{|c|c|c|c|c|c|c|c|c|}
\hline \multirow[b]{2}{*}{ Analysis } & \multirow{2}{*}{$\begin{array}{l}\text { Analysis } \\
\text { Method }\end{array}$} & \multicolumn{3}{|c|}{ Palm Shell Origin } & \multicolumn{2}{|c|}{ Woody Biomass } & \multirow{2}{*}{$\begin{array}{c}\text { Candlenut } \\
\text { Shell }\end{array}$} & \multirow{2}{*}{$\begin{array}{c}\text { Cacao } \\
\text { Peel }\end{array}$} \\
\hline & & Riau & $\begin{array}{c}\text { Kalimantan } \\
\text { Tengah }\end{array}$ & Lampung & Kaliandra & Gamal & & \\
\hline \multicolumn{9}{|c|}{ Proximate Analysis (adb) } \\
\hline Moisture & ASTM D.3173 & $12.80 \%$ & $11.59 \%$ & $13.06 \%$ & $7.07 \%$ & $6.59 \%$ & $5.02 \%$ & $14.53 \%$ \\
\hline Volatile Matter & ISO 562 & $65.39 \%$ & $67.21 \%$ & $65.58 \%$ & $69.79 \%$ & $71.20 \%$ & $63.16 \%$ & $60.95 \%$ \\
\hline Fixed Carbon & ASTM D.3172 & $20.06 \%$ & $19.85 \%$ & $18.29 \%$ & $19.53 \%$ & $19.29 \%$ & $26.73 \%$ & $18.42 \%$ \\
\hline Ash & ASTM D.3174 & $1.75 \%$ & $1.35 \%$ & $3.07 \%$ & $3.61 \%$ & $2.92 \%$ & $5.09 \%$ & $7.97 \%$ \\
\hline \multicolumn{9}{|c|}{ Ultimate Analysis (adb) } \\
\hline Carbon & ASTM D.5373 & $46.83 \%$ & $47.72 \%$ & $45.96 \%$ & $44.59 \%$ & $44.80 \%$ & $49.54 \%$ & $39.87 \%$ \\
\hline Hydrogen & ASTM D.5373 & $6.88 \%$ & $6.81 \%$ & $6.93 \%$ & $6.20 \%$ & $6.41 \%$ & $5.64 \%$ & $5.96 \%$ \\
\hline Nitrogen & ASTM D.5373 & $0.37 \%$ & $0.34 \%$ & $0.43 \%$ & $1.15 \%$ & $1.01 \%$ & $0.38 \%$ & $0.74 \%$ \\
\hline Total Sulfur & ASTM D.4239 & $0.14 \%$ & $0.15 \%$ & $0.14 \%$ & $0.18 \%$ & $0.07 \%$ & $0.04 \%$ & $0.13 \%$ \\
\hline Oxygen & ASTM D.3176 & $44.03 \%$ & $43.63 \%$ & $43.47 \%$ & $44.27 \%$ & $44.79 \%$ & $39.31 \%$ & $45.33 \%$ \\
\hline GHV (MJ/kg) & ASTM D.5865 & 17.9 & 18.2 & 17.9 & 17.8 & 17.8 & 19.2 & 15.4 \\
\hline
\end{tabular}

The palm shell is also possible to produce combustible gases via gasification process for substituting fossil fuel in a diesel, gasoline or gas engine. In general, biomass gasification is a complex chemical reaction between biomass as a source of carbon and hydrogen with less than stoichiometric gasifying agents to produce combustible gases. Basically, the gasifying agents may include air, enriched air, oxygen, steam, $\mathrm{CO}_{2}$ or any combination of those. This reaction takes place in a certain type of gasifier at an elevated temperature. Depending on the source of oxygen, the gaseous product may contain $\mathrm{CO}, \mathrm{H}_{2}, \mathrm{CO}_{2}, \mathrm{CH}_{4}$, and solid residue, ash and tarry components in the small amount $[4,5]$. This tar components may arise critical problems to the engine as decreasing of gas utilizations and needs more maintenance as blockage in piping system and even on the piston [5]. A clean gas contains more hydrogen and carbon monoxide are not only combustible, but the gas would be also useful as raw materials for producing many kinds of chemicals in a Fischer-Tropsch Process (FTP) unit [6].

Recently, many methods of tar reduction or gas cleaning to improve gas quality are already proposed. They are classified into two main methods, primary and secondary. The primary method is carried out in the gasifier including improvement on gasification reactor design and structure, addition of secondary air piping system, catalytic cracking, two-stage air and premixed air/gas supply [7-13]. Secondary methods use additional systems for cleaning the outlet gas products, such as electrostatic precipitator, wet scrubber, fabric filters or cyclone separators. Not only for tar collecting, but also this method offers higher efficiency for isolating $\mathrm{NH}_{3}$, $\mathrm{H}_{2} \mathrm{~S}$, and $\mathrm{HCl}$ which may include in the producer gas. As consequences, this method needs more capital and operating expenditure $[7,8]$.

This research implemented primary method by recycling a certain portion of producer gas into the pyrolysis zone of gasifier after mixing it with the secondary air. It keeps the pyrolysis zone temperature stable. Palm shells were the raw material for producing the gas. A downdraft fixed bed gasifier was applied in this research as this produces less tar component compared to others type. This studied the effects of recycle gas flow-rate on gasification temperature, producer gas composition including tar content, and gasifier performance.

\section{Methodology}

\subsection{Chemical composition analysis}

The palm shells for this research were collected from solid residues of a palm oil milling in Riau Province. Before using for the experiments, a typical sample of the shells were analyzed for chemical compositions and calorific value in a certified testing laboratory. For comparison, palm shell samples from Kalimantan Tengah Province and Lampung Province, Kaliandra Wood (Calliandra calothyrsus), Gamal Wood (Gliricidia sepium), candlenut (Aleurites moluccana) shell, and cocoa (Theobroma cacao) peel were also analyzed (Table 2).

\subsection{Experimental setup}

Figure 1 presents experimental setup during this study. This research applied a throated downdraft gasifier for gasifying of palm shell using air as gasifying agent. The throat diameter is $0.10 \mathrm{~m}\left(S=0.0079 \mathrm{~m}^{2}\right)$ and the total height is $1.00 \mathrm{~m}$. It was also equipped with a shaker in the bottom part for taking the ash out frequently. Feeding of palm shells was carried out manually. A twohorsepower blower supplied primary air into the top of the gasifier and secondary air into the reduction zone. Each flow-rate was monitored with rotameters and controlled by adjusting valves. The temperature of the reduction zone was also monitored with a K-type thermocouple which worked in the temperature range of $0-1200^{\circ} \mathrm{C}$. A producer gas recycle system was installed between the product gas outlet-line and the secondary air inlet-line. The recycle gas flow-rate was observed with a calibrated orifice and U-manometer set and controlled by 
adjusting a valve. The flow of this gas occurred as a jet ejector was assembled in the secondary air pipe line which also functioned as gas-mixer.

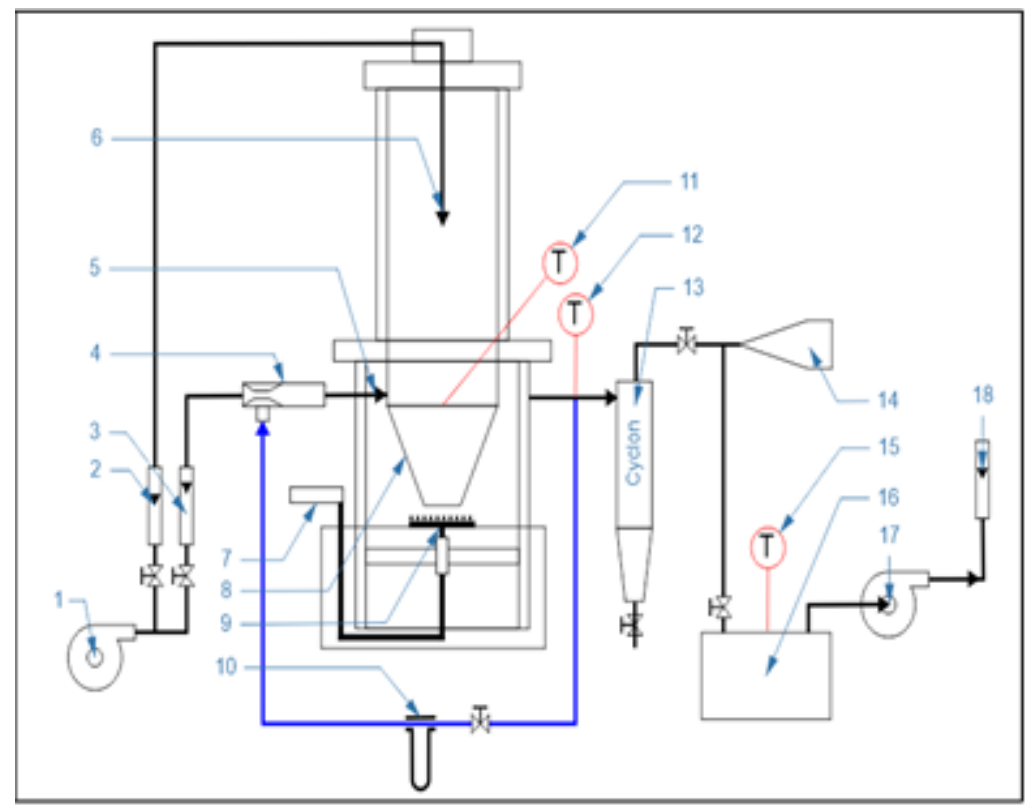

\author{
Annotation: \\ 1. air blower \\ 2. primary air flow-meter \\ 3. secondary air flow-meter \\ 4. jet ejector \\ 5. secondary air inlet \\ 6. primary air inlet \\ 7. shaker \\ 8. throat \\ 9. ash grate \\ 10. recycle gas flow-meter \\ 11. reduction zone thermocouple \\ 12. producer gas thermocouple \\ 13. cyclone separator \\ 14. gas burner \\ 15. therm ometer \\ 16. impinger box \\ 17. vacuum pump \\ 18. gas flow-meter
}

Fig. 1. Experimental setup.

The experimental setup also comprised of cyclone separator, gas burner, impinger box, and vacuum pump. The cyclone functioned as ash separator, thus the gas would be solid particle free before analyzing. A gas burner was installed to indicate that the gas already contained combustible compounds and was ready to be sampled for analyzing. An impinger box consisted of four tubes filled with $50 \mathrm{~mL}$ of isopropyl alcohol for isolating tar components in the gas stream and one empty tube. This sampling method conformed to the Guideline for Sampling and Analysis of Tar and Particle in Biomass Producer Gases [14].

\subsection{Experimental steps}

Initially, the reactor was preheated by burning $0.5 \mathrm{~kg}$ of Calliandra calothyrsus. Five kilograms of palm shells were fed into the gasifier when the gasifier temperature was about $150-200^{\circ} \mathrm{C}$ at every run. The gasification operations were carried out with four operating modes. The first (Run K-1) used only primary air as gasifying agent at flow-rate of $3.30 \mathrm{Nm}^{3} / \mathrm{h}$. Run K-2 applied both primary air flow-rate at $1.80 \mathrm{Nm}^{3} / \mathrm{h}$ and secondary air flow-rate at $1.50 \mathrm{Nm}^{3} / \mathrm{h}$. By keeping both air flow-rates constant as much as Run K-2, recycle gas flow-rate at $0.90 \mathrm{Nm}^{3} / \mathrm{h}$ and $1.20 \mathrm{Nm}^{3} / \mathrm{h}$ were implemented respectively (Run K-3 and K-4).

When the outlet gas indicated formation of combustible components, then gas sample was sucked at gas flow-rate of $0.03 \mathrm{Nm}^{3} / \mathrm{h}$ into impinger box with a vacuum pump. In the box, the tar components condensed and dissolved in isopropyl alcohol solvent. After evaporating the solvent, the tar residue was weighed and the tar content in the gas was calculated as Equation (1).
Tar content $=\frac{m_{\mathrm{tar}}}{V_{g a x}}$

$m_{\text {tar }}$ is dry tar weight and $V_{\text {gas }}$ is gas sample volume during a certain run.

The clean gas during each run was also sampled for chemical composition analysis with Gas Chromatography method (using Shimadzu GC-2014 with TCD-14 sensor). The combustible gas high heating value was estimated with Equation (2).

$$
H H V=y_{C O} H H V_{C O}+y_{H 2} H H V_{H 2}+y_{C H 4} H H V_{C H 4}
$$

After finishing the process, the solid residue of gasification was weighed for specific gasification rate (SGR) calculation [15] as Equation (3). The SGR is defined as the amount of biomass fuel used per unit time per unit throat cross-sectional area. This describes the reactor design performance.

$$
S G R=\frac{G_{E}}{S}
$$

Where: $G_{t}$ is fuel mass flow rate and $S$ is throat crosssectional area.

\section{Results and discussion}

Reduction zone temperature profile of all operating modes are presented in Figure 2. Gasification with only primary air as gasifying agent (Run K-1) showed the lowest temperature profile at $651^{\circ} \mathrm{C}$ in average which indicated that the reaction did not occur perfectly. It was also found that the solid residue was more than other runs. This was caused by insufficient and ununiformed distribution of gasifying agent supply as primary air gas inlet was installed above the fresh feed bed. 
By using secondary air in Run $\mathrm{K}-2$, the average temperature attained $707^{\circ} \mathrm{C}$. The secondary air inlet which was installed in the reduction zone increased supply and distributed the air better, thus more biomasses were gasified. In addition to that, a throat in this zone also affected gasification rate and reaction completeness. According to the previous study [11], the throat size influences downdraft gasifier efficiency. In general, the design and structure of the reactor are also should be considered when an optimum gasification reaction is expected $[4,5,10]$. It is also obvious that $\mathrm{CO}_{2}$ content in the gas increased when more gasifying agent applied in Run K-2. Carbon dioxide formation as a result of oxidation released energy, thus the temperature would increase. While, increasing recycle gas flow-rate resulted insignificant change of $\mathrm{CO}_{2}$ though the temperature rise.

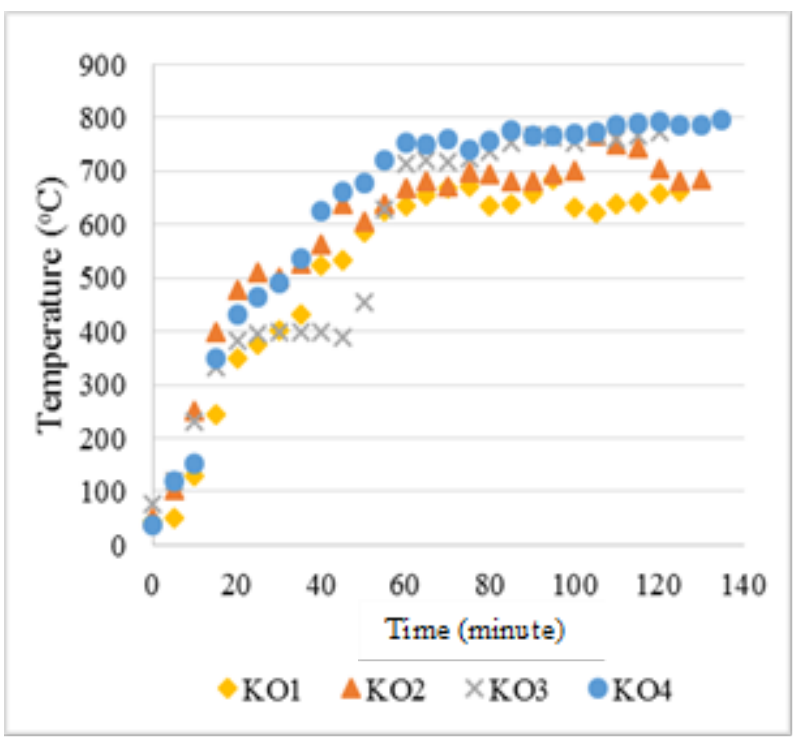

Fig. 2. Temperature profile in reduction zone.

It was observed that the more recycle gas flow-rate the higher the gasification temperature. At recycle gas flow-rate of $0.90 \mathrm{Nm}^{3} / \mathrm{h}$ and $1.20 \mathrm{Nm}^{3} / \mathrm{h}$, the average temperatures were $750^{\circ} \mathrm{C}$ and $779^{\circ} \mathrm{C}$ respectively. These showed that gasification reaction took place more perfect. This trend is similar to previous study [8, 9]. Besides, the $\mathrm{CO}$ content in recycle gas might also increase gasification reaction [16].

Table 3. Clean synthetic gas composition.

\begin{tabular}{|c|c|c|c|c|c|c|c|c|c|}
\hline \multirow{2}{*}{$\begin{array}{c}\text { Mode of } \\
\text { operation }\end{array}$} & \multirow{2}{*}{$\begin{array}{c}\text { Reactor } \\
\text { temperature }\left({ }^{\circ} \mathrm{C}\right)\end{array}$} & \multirow{2}{*}{$\begin{array}{c}\text { Tar content } \\
\left(\mathrm{g} / \mathrm{Nm}^{3}\right)\end{array}$} & \multicolumn{5}{|c|}{ Synthetic gas composition } & \multirow{2}{*}{\multicolumn{2}{|c|}{$\begin{array}{l}\mathbf{I} \\
\text { (M..... }\end{array}$}} \\
\hline & & & $\mathrm{CO}_{2}$ & $\mathrm{H}_{2}$ & $\mathbf{N}_{2}$ & CO & $\mathrm{CH}_{4}$ & & \\
\hline $\mathrm{K} 1$ & 651 & 118.0 & $6.95 \%$ & $10.92 \%$ & $68.83 \%$ & $11.03 \%$ & $2.27 \%$ & 3.82 & 85.6 \\
\hline $\mathrm{K} 2$ & 707 & 68.1 & $10.91 \%$ & $10.65 \%$ & $56.10 \%$ & $17.38 \%$ & $4.95 \%$ & 5.72 & 95.0 \\
\hline $\mathrm{K} 3$ & 750 & 44.9 & n.a. & n.a. & n.a. & n.a. & n.a. & n.a. & 111.7 \\
\hline $\mathrm{K} 4$ & 779 & 51.4 & $10.81 \%$ & $11.68 \%$ & $52.69 \%$ & $19.32 \%$ & $5.51 \%$ & 6.34 & 107.5 \\
\hline
\end{tabular}

K1: Primary air

K2: Mixture of primary and secondary air

K3: Mixture of primary air, secondary air and recycled gas at rate of $0.90 \mathrm{~m}^{3} / \mathrm{h}$

K4: Mixture of primary air, secondary air and recycled gas at rate of $1.20 \mathrm{~m}^{3} / \mathrm{h}$

An increase in gasification operating temperature also affects the tar content in producer gas. Without recycle, the higher the temperature, the lower the tar content as the tar would crack at higher temperature [17]. Table 3 shows the results of this research. The tar content as the result of Run K-1 was observed at the amount of $118 \mathrm{~g} / \mathrm{Nm}^{3}$. As temperature increased due to recycle gas application, the lowest tar content was observed at Run K-3 (at recycle gas flow rate of 0.90 $\mathrm{Nm}^{3} / \mathrm{h}$ ) and increased when the recycle gas flow rate was $1.20 \mathrm{Nm}^{3} / \mathrm{h}$ (Run K-4). This also conformed to other study [9]. In addition to that, Run K-3 showed the highest SGR $\left(111.7 \mathrm{~kg} / \mathrm{m}^{2} \mathrm{~h}\right)$. The SGR decreased slightly to $107.5 \mathrm{~kg} / \mathrm{m}^{2} \mathrm{~h}$ when the recycle gas flow-rate increased from 0.90 to $1.20 \mathrm{Nm}^{3} / \mathrm{h}$. This might cause by faster residence time of biomass in the gasifier due to higher recycle gas flow-rate [18]. The design and structure of gasifier were also the possible causes of this phenomenon. This might also include secondary air distribution. However, all the runs resulted higher tar content in the gas rather than gas requirement for fueling internal combustion engine [19].

As consequences of increasing combustible gases in producer gas stream, the high heating value also increased. Run K-4 resulted the highest content (36.51\%) of combustible gases compared to Run K-1 (25.77\%). This increased the HHV of the gas by $65.9 \%$ because the $\mathrm{CO}$ content increased by $75.2 \%$ although the heating value is lower than methane.

\section{Conclusions}

Recycle system in a throated downdraft fixed bed gasifier increased the gasification temperature from 
$650^{\circ} \mathrm{C}$ to $778^{\circ} \mathrm{C}$. As a result, the specific gasification rate rises $30 \%$ to $111.7 \mathrm{~kg} / \mathrm{m}^{2} \mathrm{~h}$.

With recycle rate at $0.90 \mathrm{Nm}^{3} / \mathrm{h}$, tar content in producer gas dropped to $44.92 \mathrm{~g} / \mathrm{Nm}^{3}$ from $118 \mathrm{~g} / \mathrm{Nm}^{3}$. The combustible gas content in syngas was observed in the amount of $37 \%$ and the calculated heating value of the syngas was $6.34 \mathrm{MJ} / \mathrm{Nm}^{3}$.

\section{References}

1. S.K. Loh, Energy Convers. Manag. 141, 285-298 (2017)

2. W. Patthainaissaranukool, C. Polprasert, A.J. Englande Jr., Appl. Energy 102, 710-717 (2013)

3. Q. Wu, T.C. Qiang, G. Zeng, H. Zhang, Y. Huang, Y. Wang, Int. J. Hydrog. Energy 42, 23871-23877 (2017)

4. A.A.P. Susastriawan, H. Saptoadi, Purnomo, Renew. Sust. Energ. Rev. 76, 989-1003 (2017)

5. A. Surjosatyo, F. Vidian, Y.S. Nugroho, Jurnal Mekanikal Universitas Indonesia 31, 63-67 (2010)

6. G. Herz, E. Reichelt, M. Jahn, Energy 132, 370-381 (2017)

7. D. Swierczyński, S. Libs, C. Courson, A. Kiennemann, Appl. Catal., B 74, 211-222 (2007)

8. L. Devi, K.J. Ptatinski, F.J.J.G. Janssen, Biomass Bioenergy 24 125-140 (2003)

9. K. Jaojaruek, S. Jarungthammachote, M.K.B. Gatruito, H. Wongsuwan, S. Homhual, Bioresour. Technol 102, 4834-4840 (2011)

10. M.M. Omar, A. Munir, M. Ahmad, A. Tanveer, J. Energy Inst. (in Press, Corrected Proof)

11. L.E. Taba, M.F. Irfan, W.A.M.W. Daud, M.H. Chakrabarti, Renew. Sust. Energ. Rev. 16, 55845596 (2012)

12. S. Bunchan, T. Poowadin, K. Trairatanasirichai, Energy Procedia 138, 745-750 (2017)

13. Y. Cao, W. Wang, J.T. Riley, W.P. Pan, Fuel Process. Technol. 87, 343-353 (2006)

14. J. Neeft, H. Knoef, G.J. Buffinga, U. Zielke, K. Sjöström, C.O. Brage, P. Hasler, P.A. Smell, M. Soumalainen, M.A. Dorrington, C. Greil, Progress in Thermochemical Biomass Conversion, Ch. 11, 162-175 (2008)

15. N.V. Lanh, N.H. Bich, N.N. Quyen, B.N. Hung, T.R. Preston, Livestock Research for Rural Development, 30 (2018)

16. J. Fermoso, B. Arias, M.G. Plaza, C. Pevida, F. Rubiera, J.J. Pis, F. García-Peña, P. Casero, Fuel Process. Technol. 90, 926-932 (2009)

17. P. Chaiprasert, T. Vitidsant, Am. J. Appl. Sci. 6, 332-336 (2009)

18. X. Xiao, X. Meng, D.D. Le, T. Takarada, Bioresour. Technol. 102, 1975-1981 (2011)

19. S. Dasappa, H.V. Sridhar, G. Sridhar, P.J. Paul, H.S. Mukunda, Biomass Bioenergy 25, 637-649 (2003) 